\title{
Peningkatan Kesadaran Bahaya Asap Rokok Bagi Kesehatan Pada Siswa SMP Negeri 1 Tegal
}

\author{
Agus Susanto*1, Rosaria Ika Pratiwi², Ahmad Sunardi ${ }^{3}$ \\ 123Program Studi D3 Farmasi, Politeknik Harapan Bersama \\ Jalan Mataram No. 9 Pesurungan Lor, Kota Tegal \\ *e-mail: agusus@yahoo.com
}

\begin{abstract}
Schools as non-smoking areas (KTR) have not been maximized to implement smoking behavior prevention programs for students. The health education requires efforts to strengthen students' knowledge and attitudes about smoking behavior and its dangers to health. This community service (PKM) activity aims to increase students' knowledge and awareness of the dangers of cigarette smoke for health. The main target in this activity is 8th grade and 9th grade $j$ public junior high school students \#1 Tegal. This activity was carried out for two days divided into the first day was pretest and on the second day the activity was carried out. Measurement of increasing knowledge is based on the difference between the pretest score and the post test score. The results of the activity showed a significant increase in knowledge and attitudes, which was indicated by a mean pretest score of 10 and a mean posttest score of 12.20. Improvements also occurred in student attitudes, as indicated by the mean pretest value of 62.62 and the posttest value of 67.02.
\end{abstract}

Keywords: Awareness raising, the dangers of cigarette smoke, health education, junior high school students

\begin{abstract}
Abstrak
Sekolah sebagai kawasan tanpa rokok (KTR) belum maksimal untuk melaksanakan program pencegahan perilaku merokok pada siswa. Kegiatan penyuluhan kesehatan diperlukan untuk memperkuat pengetahuan dan sikap siswa tentang perilaku merokok dan bahayanya bagi kesehatan. Kegiatan pengabdian kepada masyarakat (PKM) ini bertujuan untuk meningkatkan pengetahuan dan kesadaran siswa akan bahaya asap rokok bagi kesehatan. Target utama dalam kegiatan ini siswa laki-laki kelas 8 dan 9 SMP Negeri 1 Tegal. Kegiatan ini dilaksanakan selama dua hari yang terbagi atas hari pertama adalah pretes dan di hari kedua pelaksanaan kegiatan. Pengukuran peningkatan pengetahuan berdasarkan selisih skor pretes dan nilai post tes. Hasil dari kegiatan menunjukkan adanya peningkatan pengetahuan dan sikap yang cukup signifikan, yang ditunjukkan skor mean pretes sebesar 10 dan nilai mean postes sebesar 12,20. Peningkatan juga terjadi pada sikap siswa, yang ditunjukkan dengan nilai mean pretes sebesar 62,62 dan nilai postes sebesar 67,02.
\end{abstract}

Kata kunci: Peningkatan kesadaran, bahaya asap rokok, penyuluhan kesehatan, siswa SMP

\section{PENDAHULUAN}

Perilaku merokok merupakan permasalahan yang susah untuk diatasi karena permasalahan ini begitu kompleks. Perilaku ini seakan telah menjadi bagian dari budaya masyarakat. Dalam berbagai kegiatan kemasyarakatan hampir selalu disediakan rokok oleh pihak penyelenggara. Perokok seakan memiliki hak prerogratif tentang di mana dan kapan melakukan kegiatan tersebut. Hal ini diperparah dengan framing media yang menggambarkan bahwa rokok sebagai simbol kejantanan (Trisnowati et al., 2015, Dahal, Maharjan et al., 2015).

Meski perilaku merokok sangat lazim dilakukan ditengah masyakarat, namun faktanya perilaku ini mamiliki dampak yang sangat besar. WHO melaporkan bahawa setiap tahuan terdapat tujuh juta orang meninggal setiap tahunnya. Enam juta diantaranya adalah perokok aktif dan selebihnya berasal dari orang-orang yang tidak merokok namun mendapatkan paparan asap rokok dalam waktu yang panjang (WHO, 2018)

Dampak perilaku rokok yang merugikan tersebut tidak serta merta membuat orang untuk menolak perilaku ini. Berdasarkan data WHO (2018) jumlah perokok di dunia terus mengalami peningkatan. Jumlah perokok di dunia diperkirakan berkisar di angka 1.1. miliar. 80 $\%$ dari jumlah tersebut berasal dari negara-negara berkembang sepert Indonesia. Jumlah 
perokok di Indonesia adalah nomor satu di Asia Tenggara dan urutan ketiga di dunia setelah Tiongkok dan India. (Prabandari \& Dewi, 2016 ; Kemenkes RI, 2015)

Data Riskesdas tahun 2018 menunjukkan bahwa prevalensi perokok pada usia dewasa mengalami kenaikan sebesar $1 \%$ di mana pada tahun 2016 dengan prevalensi perokok sebesar 32,8 \% menjadi 33,8 \% pada tahun 2018 (Badan Penelitian dan Pengembangan Kesehatan, 2018). Kenaikan jumlah perokok di Indonesia tidak hanya pada kelompok umur dewasa saja tetapi juga pada kelompok umur remaja. Kenaikan ini terjadi dengan cukup signifikan. Pada tahun 2013 prevalensi merokok remaja sebanyak 7.2\%. Pada tahun 2016 prevalensi perokok remaja naik menjadi $8.8 \%$. Tahun 2018 prevalensi perokok remaja adalah 9,1\%. Selama tiga tahun terjadi kenaikan 1,9 \% (Badan Penelitian dan Pengembangan Kesehatan, 2018).

Fenomena merokok pada remaja yang tinggi juga terjadi pada level Kota Tegal. Berdasarkan penelitian Dinkes pada Tahun 2014 menunjukkan bahwa dari 416 siswa SMP terdapat 123 siswa $(33,61 \%)$ memiliki kebiasaan merokok dan 35 orang $(9,56 \%)$ pernah merokok (Dinkes Kota Tegal, 2015). Angka ini bukanlah angka yang kecil dan tidak boleh disepelekan. Apabila hal ini dibiarkan akan berdampak pada kenaikan jumlah perokok remaja di Kota Tegal. Kenaikan ini akan berimbas pada kualitas derajat kesehatan, sosial maupun ekonomi remaja tersebut (Bahtiar, 2018; Gendall, Hoek, \& Gendall, 2018).

Secara umum sebenarnya Pemerintah telah menyadari akan dampak merokok pada remaja. Hal ini terbukti adanya Peraturan Bersama Menteri Kesehatan dan Menteri Dalam Negeri No.188/Menkes/PB/I/2011 No. 7 Tahun 2011 tentang Pedoman Kawasan Tanpa Rokok sebagai upaya kesehatan bagi seluruh masyarakat. Pemkot Kota Tegal juga telah merespon peraturan menteri tersebut dengan mengeluarkan Perwali (Peraturan Walikota) No. 13 tahun 2014 tentang kawasan tanpa rokok (KTR) yang mengatur perilaku merokok di kawasan publik.

Peraturan tentang kawasan tanpa rokok tersebut memang telah diadopsi dan dilaksanakan di sekolah-sekolah menengah pertama (SMP) di Kota Tegal. KTR ini telah membantu dalam mengatasi perilaku merokok remaja, namun masih belum terjadi secara signifikan (Marchel, 2019). Peraturan tersebut perlu dibarengi dengan program-program promosi kesehatan untuk memaksimalkan upaya pencegahan perilaku merokok (Pertiwi et al., 2018)

Pencegahan perilaku merokok pada remaja awal (early tenager) perlu dilakukan secara intensif. Pencegahan ini tidak boleh hanya mengandalkan papan pengumuman saja tetapi perlu dilakukan pendekatan komunikasi tatap muka (Bala, Senduk, \& Boham, 2015). Komunikasi tatap muka tidak hanya akan membantu dalam menyebarkan informasi tentang rokok dan bahayanya bagi kesehatan, namun juga efektif dalam melakukan tindakan persuasi (Mustafa et al., 2019). Melalui kegiatan PKM diharapkan dapat meningkatkan pengetahuan dan kesadaran siswa SMPN 1 Tegal tentang bahaya asap rokok bagi kesehatan.

\section{METODE}

Berdasarkan permasalahan yang terjadi pada para siswa SMP Negeri 1 Tegal, diperlukan suatu konsep edukasi mengenai dampak penggunaan rokok sehingga dapat menurunkan proporsi perokok di lingkungan SMP Negeri 1 Tegal. Kegiatan Pengabdian Masyarakat (PKM) yang dilakukan oleh tim PKM dengan memberikan penyuluhan tentang bahaya merokok bagi kesehatan. Kegiatan PKM ini merupakan bagian dari rangkaian kegiatan edukasi peningkatan bahaya merokok yang telah dilaksanakan oleh guru dan siswa beberapa minggu sebelum kegiatan PKM. Kegiatan PKM ini difokuskan pada kegiatan penyuluhan dengan topik bahaya menjadi Perokok Pasif.

Kegiatan Pengabdian Kepada Masyarakat (PKM) bertempat di SMP Negeri 1 Tegal yang beralamat di Jl. Tentara Pelajar No. 32 Panggung, Tegal Timur. Kegiatan ini dilaksanakan pada tanggal 11-12 Desember 2019. Sasaran Kegiatan PKM adalah 40 siswa laki-laki kelas 8 dan 9. Kegiatan PKM ini dilaksanakan oleh 3 dosen dan dibantu oleh 2 mahasiswa D3 Farmasi Politeknik Harapan Bersama. Pada kegiatan ini mahasiswa bertugas untuk membantu dalam penyebaran kueisoner, pembagian materi PKM dan pembagian snack kepada peserta PKM. 
Kegiatan dilakukan dengan tahapan survei dan analisis lapangan, penyuluhan, penayangan video dan dan tanya jawab. Kegiatan diakhiri dengan pemberian postes kepada peserta dengan cara menyebarkan kueisioner.

\section{HASIL DAN PEMBAHASAN}

\section{Pelaksanaan Kegiatan Pengabdian Kepada Masyarakat}

Kegiatan pengabdian kepada masyarakat dengan tema peningkatan kesadaran bahaya asap rokok vagi kesehatan dimulai dengan survey dan perijinan kepada pihak sekolah. Pelaksanaan kegiatan dilaksanakan selama dua hari yaitu tangal 11 dan 12 Desember 2019. Kegiatan hari pertama adalah dengan melaksanakan pretes kepada 40 peserta PKM. Pretes dilaksanakan untuk mengetahui tingkat pengetahuan dan sikap siswa yang menajdi sasaran kegiatan tentang bahaya perilaku merokok.

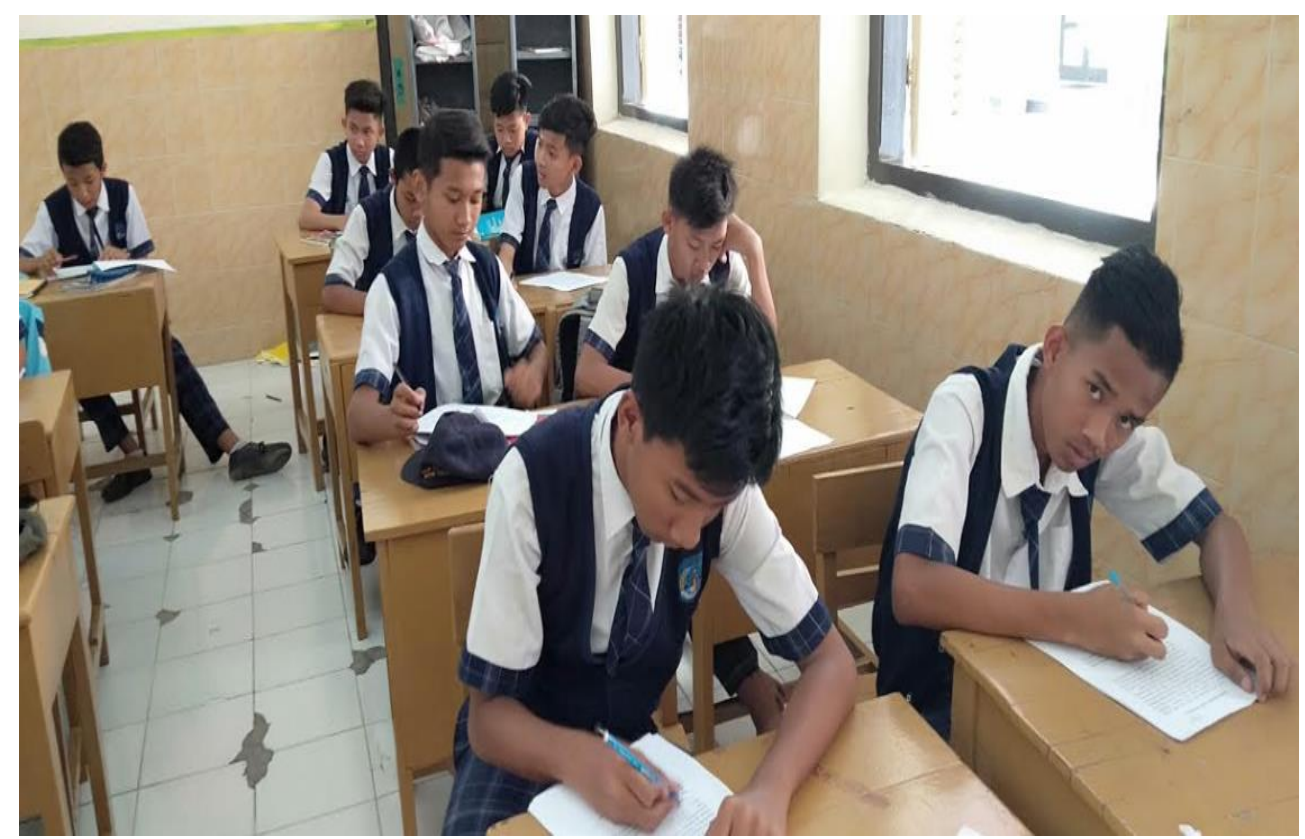

Gambar 1. Pelaksanaan Pretes (dokumen pribadi)

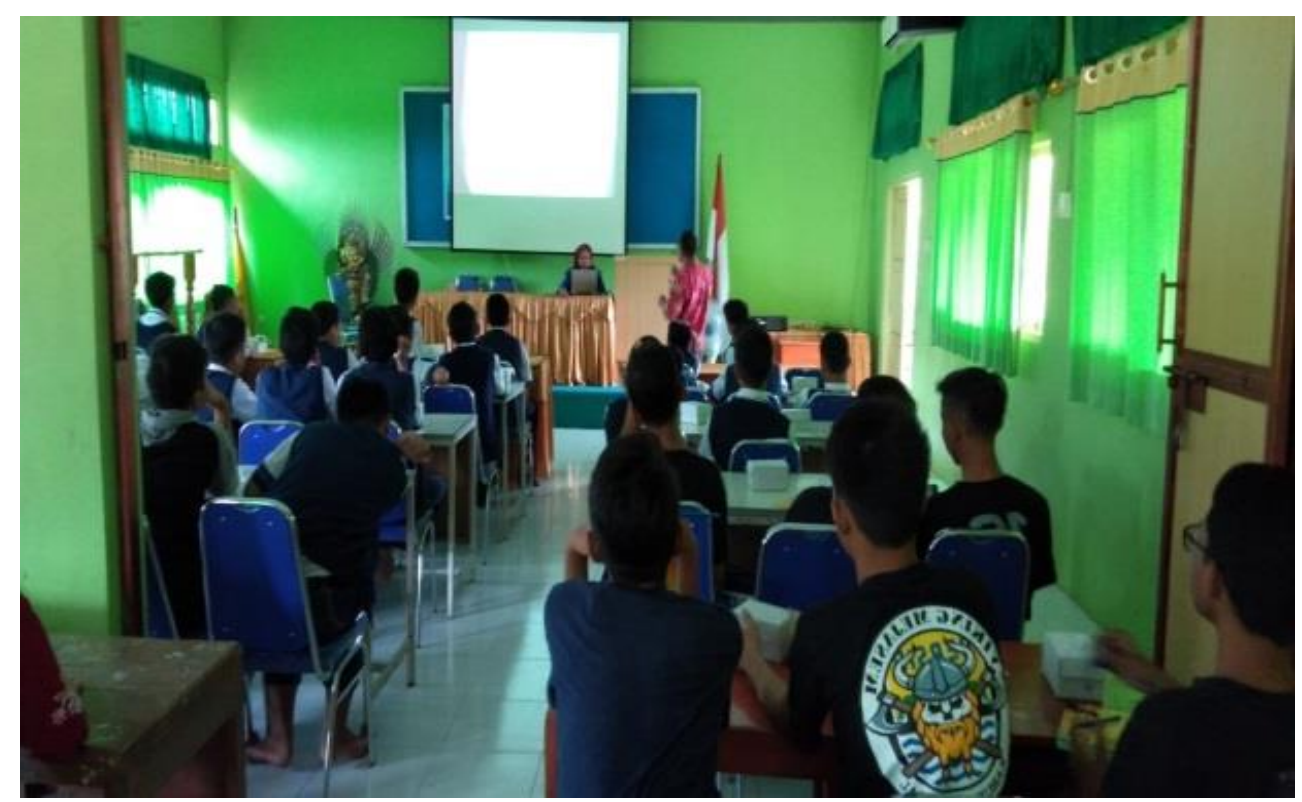

Gambar 2. Penyampaian Materi PKM (dokumen pribadi) 


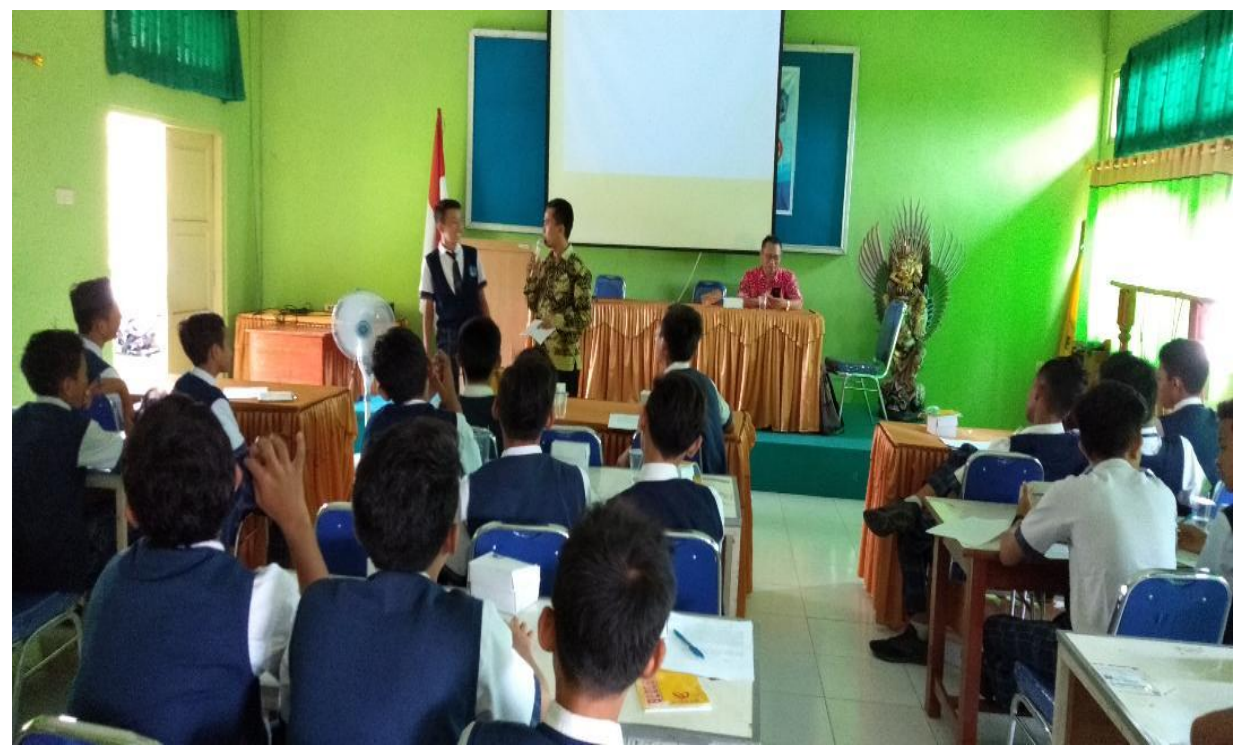

Gambar 3. Sesi tanya jawab (dokumen pribadi)

Kegiatan inti dari PKM dilaksanakan pada hari kedua tepatnya pada tanggal 12 Desember 2019. Pelaksanaan pengabdian kepada masyarakat terbagi ke dalam beberapa segmen. Segmen acara tersebut adalah penyampaian materi. Materi tentang bahaya rokok disampaikan oleh Tim PKM dan Dinas Kesehatan Kota Tegal. Penyampaian materi diakhiri dengan pemutaran film yang menceritakan tentang dampak rokok bagi kesehatan. Kegiatan PKM selanjutnya adalah sesi tanya jawab. Sesi ini dilaksanakan untuk memperkuat materi PKM sehingga siswa memiliki pemahaman yang kuat tentang bahaya rokok bagi kesehatan. Sesi terakhir dari kegiatan ini adalah pelaksanaan postes.

\section{Capaian Yang Didapat b. Hasil pengukuran tingkat pengetahuan}

Pada kegiatan PKM dilakukan pretes dan postes pada semua peserta (40 siswa). Pengukuran pada pretes dan postes menggunakan kuesioner yang berisi 14 butir pernyataan pengetahuan. Apabila jawaban benar mendapat skor 1 dan apabila salah mendapatkan skor 0 , sehingga nilai total maksimal pada 1 peserta adalah 14 dan nilai minimal 0. Melalui PKM telah berhasil meningkatkan pengetahuan siswa tentang perilaku merokok dan dampaknya bagi kesehatan. Hasil pengkuran tersebut tersaji dalam tabel di bawah ini :

Tabel 1. Hasil pengukuran pengetahuan siswa

\begin{tabular}{lcccc}
\hline & $\mathbf{N}$ & Skor total & Mean & $\boldsymbol{\Delta}$ (mean) \\
\hline Pretes & 40 & $400(71 \%)$ & 10,00 & \multirow{2}{*}{2,20} \\
Postes & 40 & $480(86 \%)$ & 12,20 & \\
\hline
\end{tabular}

Berdasarkan tabel di atas menunjukkan bahwa terdapat kenaikan nilai rata-rata pengetahuan siswa tentang rokok dan bahayanya sebesar 2,20 dan kenaikan nilai total sebesar $15 \%$ di mana pada pengukuran pretes sekor total adalah 400 atau $71 \%$ sedangkan nilai postes adalah 480 atau sebesar $86 \%$.

\section{b. Hasil Pengukuran Sikap tentang Bahaya Asap rokok}

Pengukuran sikap siswa tentang rokok dan bahaya dilakukan melalui pretes dan postes pada semua peserta (40 siswa). Pengkuran pada pretes dan postes menggunakan kuesioner yang berisi 15 butir pernyataan sikap dengan skala likert. Apabila jawaban maskimal 
mendapat skor 5 dan apabila minimal mendapatkan skor 1, sehingga nilai total maksimal pada 1 peserta adalah 75 dan nilai minimal 15. Melalui PKM telah berhasil meningkatkan sikap siswa tentang perilaku merokok dan dampaknya bagi kesehatan. Hasil dari pengukuran sikap pretes dan pos dapat dilihat dari tabel berikut.

Tabel 2. Hasil pengukuran Sikap Siswa

\begin{tabular}{ccccc} 
& N & Skor total & Mean & $\Delta$ (mean) \\
\hline Pretes & 40 & $2505(83,5 \%)$ & 62,62 & 4,4 \\
Postes & 40 & $2681(89 \%)$ & 67,02 & \\
\hline
\end{tabular}

Berdasarkan tabel di atas menunjukkan bahwa terdapat kenaikan nilai rata-rata pengetahuan siswa tentang rokok dan bahayanya sebesar 4,40 dan kenaikan nilai total sebesar 4,5 \% di mana pada pengukuran pretes sekor total adalah 2505 atau 83,5 \% sedangkan nilai postes adalah 2681 atau sebesar $89 \%$.

\section{KESIMPULAN}

Kegiatan pengabdian kepada masyarakat yang telah dilaksanakan kepada siswa kelas 8 dan 9 SMP Negeri 1 Tegal berlangsung dengan baik. Peserta kegiatan memiliki sikap yang postif terhadap kegiatan ini. Banyak peserta kegiatan yang secara aktif terlibat dalam sesi tanya jawab. Kegiatan PKM ini memiliki pengaruh positif terhadap terjadi peningkatan pengetahuan dan sikap siswa SMP Negeri 1 Tegal. Peningkatan pengetahuan siswa tentang bahaya rokok terjadi sebesar $15 \%$ dan peningkatan sikap siswa sebesar 4,5\%. Dengan demikian terdapat peningkatan kesadaran siswa akan bahaya asap rokok bagi kesehatan. Kegiatan sejenis perlu dilaksanakan secara berkesinambungan sehingga dapat menurunkan angka merokok pada siswa.

\section{UCAPAN TERIMA KASIH}

Kami mengucapkan terima kasih kepada Politeknik Harapan Bersama Kota Tegal melalui Pusat Penelitian dan Pengabdian Masyarakat (P3M) yang telah memberikan hibah kegiatan pengabdian kepada masyarakat.

\section{DAFTAR PUSTAKA}

Badan Penelitian dan Pengembangan Kesehatan. (2018). Hasil Utama Riskesdas 2018. Jakarta. Bahtiar, D. D. A. S. H. W. (2018). Dampak Merokok terhadap Kehidupan Sosial Remaja (Studi di Desa Mabodo Kecamatan Kontunaga Kabupaten Muna) - Neliti. Jurnal Neo Societal, 3(2).

Bala, M. E., Senduk, J., \& Boham, A. (2015). Peran Komunikasi Keluarga Dalam Mencegah Perilaku Merokok Bagi Remaja Di Kelurahan Winangun Kecamatan Malalayang Kota Manado. Acta Diurna, 4(3).

Dahal, S., Maharjan, S., Subedi, R. K., \& Maharjan, J. (2015). Role of Media in Provoking Cigarette Smoking among Adolescents in Urban Nepal. Health, 7, 98-105. https://doi.org/10.4236/health.2015.71011

Dinkes Kota Tegal. (2015). Prevalensi Perokok Usia Dini Th 2014 Di Kota Tegal. Retrieved from http://dinkes.tegalkota.go.id/berita/detail/prevalensi-perokok-usia-dini-th-2014-di-kotategal

Gendall, P., Hoek, J., \& Gendall, K. (2018). Evaluating the Emotional Impact of Warning Images on Young Adult Smokers and Susceptible Non-Smokers. Journal of Health Communication, 23(3), 291-298. https://doi.org/10.1080/10810730.2018.1440332

Kemenkes RI. (2015). Infodatin : Perilaku Merokok Masyarakat Indonesia. Jakarta: Pusat Data dan 
Informasi Kemenkes RI.

Marchel, Y. A. (2019). Implementasi Kawasan Tanpa Rokok Sebagai Pencegahan Merokok Pada Remaja Awal. Jurnal PROMKES, 7(2), 144. https://doi.org/10.20473/jpk.v7.i2.2019.144155

Mustafa, I. R., Abdillah, M. B., Winata, N. R., Pratama, R., Isnanda, R., Putra, T. D. A., \& Sulistyo, D. W. (2019). Edukasi Gerakan Siswa Anti Narkoba" (Geswana) Era Desrupsi 4.0 di Smp Wahid Hasyim Malang. Jurnal Dinamisia, 3(2). Retrieved from https://journal.unilak.ac.id/index.php/dinamisia/article/view/3214/1863

Pertiwi, C. M. P., Engkeng, S., \& Asrifuddin, A. (2018). Pengaruh Promosi Kesehatan Terhadap Pengetahuan Dan Sikap Merokok Pada Pelajar Laki-Laki Di Smk Negeri 2 Kota BitunG. Jurnal KESMAS (Vol. 7).

Prabandari, Y. S., \& Dewi, A. (2016). How do Indonesian youth perceive cigarette advertising? A cross-sectional study among Indonesian high school students. Global Health Action, 9. https://doi.org/10.3402/gha.v9.30914

Trisnowati, H., Prabandari, Y. suryo, \& Padmawati, R. S. (2015). Cigarette Advertising Exposure And Smoking Behaviour Among Teenagers At Junior High School In Bantul District Yogyakarta Special Province. Jurnal Medika Respati, 10(3).

WHO. (2018). Tobacco. Retrieved from www.who.int/topics/tobacco/en/ 